\title{
The Development Strategy of Packaged Pempek Industry
}

\author{
Railia Karneta $^{1} \&$ Nurlaili Fitri Gultom ${ }^{1}$ \\ ${ }^{1}$ Agricultural Higher School of Sriwigama, Palembang, Indonesia \\ Correspondence: Priyono, Post Graduate Management Program, Universitas Bina Darma, Palembang, Indonesia. \\ E-mail: priyono.unu_sidoarjo@yahoo.com \\ Received: March 24, 2017 \\ Accepted: June 24, 2017 \\ Online Published: July 18, 2017 \\ doi:10.5539/ijbm.v12n8p227 \\ URL: https://doi.org/10.5539/ijbm.v12n8p227
}

\begin{abstract}
The purpose of this study is to examine the factors that play a role in the development of pempek quality favored by consumers and to study internal and external factors that influence the development of pempek processing industry and its implications for strengths, weaknesses, opportunities and threats as well as formulate alternative development strategies for Pempek industry.

The sampling technique used in this study is simple random sampling with a sample area of 95 respondents consisting of 10 pempek processors (producers) and 85 consumers. Data processing is done by using factor analysis to know the dominant factor of pempek industry development. SWOT analysis is used to determine the development strategy of the pempek industry.

The results showed that the factors that play an important role in the development of pempek industry are organoleptic factors consisting of taste, color, softness and aroma; Consumer prices, food hygiene and safety with regard to physical quality, chemical quality, shelf life and strategic location. Pempek industrial development strategy that must be done is by the application of practical and efficient technology, excellent products, hygiene and security, extension of marketing network through cooperation with marketing agents both at homeland and foreign countries, cooperation, restaurant, retail and supermarket, promotional strategy improved through Advertising, leaflets, radio, television, internet and publicity.
\end{abstract}

Keywords: strategy, pempek, industry, packaging

\section{Introduction}

Pempek is Indonesia traditional food that has potential to be developed into commercial commodity either commerce amongst areas whit in Indonesia or exported to other countries. The effort to make pempek as commercial commodity is not easy because it requires quality consistency and process with efficient technology (Karneta, 2010).Pempek as commercial commodity has disadvantage due to its short shelf life and it can only hold out for two days without addition of preservative compound.

The short shelf life of pempek is due to its nutrients content such as protein, carbohydrate and lipid that can be degraded especially by microbe into components of food deterioration parameters such as ammonium, trimethyl amine, $\mathrm{H}_{2} \mathrm{~S}, \mathrm{CO}_{2}$, acids and other compounds that have putrid and rancid odors(Castro et al., 2012 ; Amegovu et al., 2012). Therefore, proper food technology is required to produce pempek with longer shelf life. The longer the product's shelf life, the farther its marketing extent resulting in more economical business (Kotler, 1997). It is time for pempek industry to produce pempek with good and informative package containing materials composition, nutrients composition and expired date as well as by constantly considering aspects of physical quality, chemical quality, microbiological quality and organoleptic quality especially in term of taste, color, aroma, rubberiness, sanitation/hygiene and food safety.

The technological consideration should be proper and integrated within the overall business strategy in tighter competition condition. Business strategy can be classified into aspects as follows: price leadership through efficiency of production and cost minimization; quality leadership through the best product's appearance and maximum value; niche leadership through fulfilling of certain product's form required by consumers (Porter, 1998), and clean technology leadership through image creation and promotion of clean environment.

It is expected that this study can produce the change on pempek industry development in particular and traditional foods in general so that pempek can achieve equal position with other foods in particular of import 
foods which apply quality as their business advantages which in turn pempek industry can participate in accelerating community economy improvement. The objectives of this research were to analyze factors that had a role in developing high quality of pempek which prefered by consumers and to study internal and external factors that affect the development of pempek processing industry and their implications on strength, weakness, opportunity and threat as well as to formulate alternative development strategy for pempek industry.

\section{Research Method}

Samping technique used in this research was simple random sampling. The simple random sampling is used when population is not very diverse or if the real proportion is in the range of 20 to 80 percent (Steel and Torrie, 1991). The respondent numbers at least should be five times of factor item numbers or $5 \mathrm{n}$ in order to conduct factor analysis (Rangkuti, 2005). The sample numbers used in this research was 95 respondentswhich consisted of 10 pempek processors (producers) and 85 consumers. The development of pempek industry is shown in Figure 1.

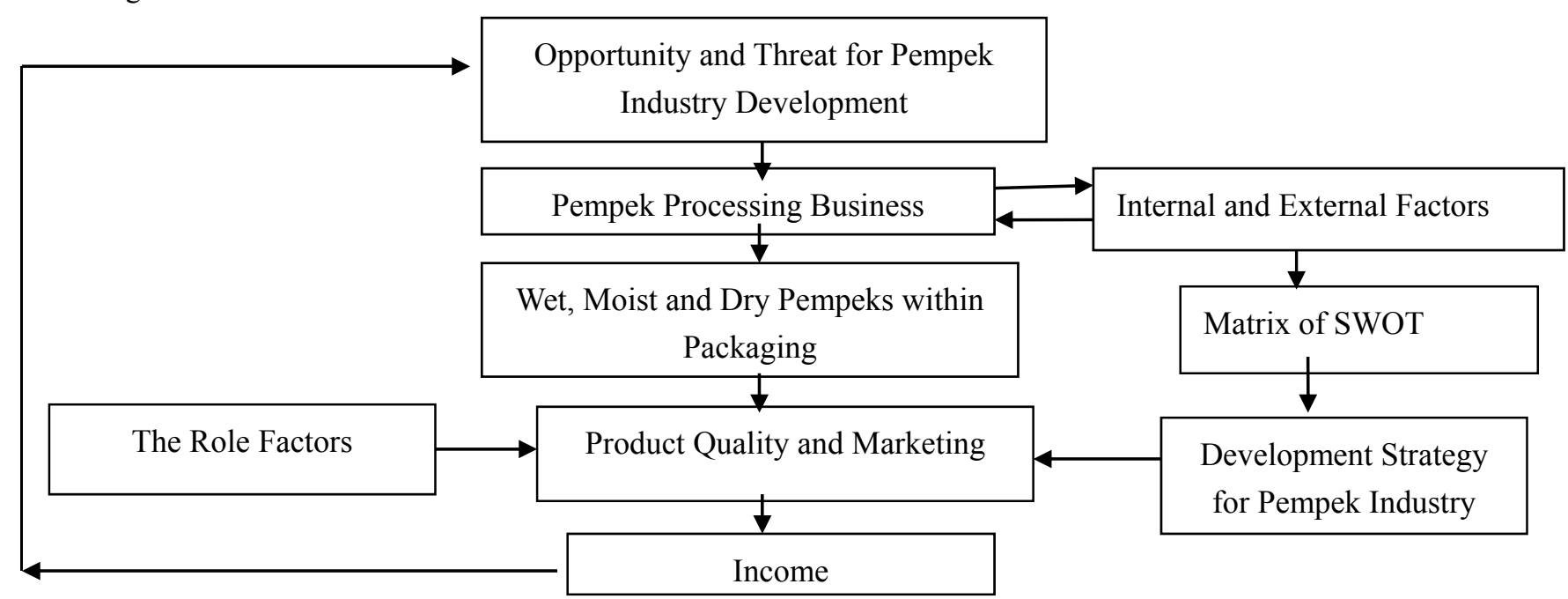

Figure 1. Frame of thinking

Data processing is conducted by using factor analysis in order to determine the dominant factors in development of high quality pempek industry with statement grouping phase that have similarities and weighting of loading factor using minimum weight criteria of 0.5 . Factors with loading value less than 0.5 are considered as having less effect. Stages used in factor analysis calculation are as follows: (a). correlation matrix development, (b). extraction conducting (initial factor) and (c). Terminal rotation conducting. The collected data and information were processed and presented in form of tabulation. The equation used in this calculation is as follows:

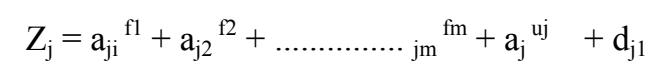

Where:

$\mathrm{Z}_{\mathrm{j}}=\mathrm{j}$ variable in standard form

f1 = Hyphothetical factor

$\mathrm{a}_{\mathrm{j} 1}=$ Multiple regression coefficient that had been standardized from variable in factor (loading factor)

$\mathrm{d}_{\mathrm{j} 1}=$ Regression coefficient from $\mathrm{j}$ variable for unique factor

The SWOT analysis is used to determine development strategy for pempek industry. SWOT analysis is one of methods that can be used to formulate development strategy for pempek industry by considering Strengths, Weaknesses, Opportunities and Threaths. SWOT analysis is started by conducting shelf evaluation in order to determine the strength and weakness for pempek industry development. The opportunity and threat are then identified which consisted of input, process and output as a results of the existing condition (David, 2003). SWOT analysis is conducted by using assumption that an effective strategy will maximize the strength and opportunity as well as minimize weakness and threat in development of pempek processing industry (Rangkuti, 2005). 


\section{Results and Discussion}

\subsection{Factor Analysis}

Results of respondents respond toward pempek industry development were consisted of 15 factors which can be summarized into 5 factor classes that had important role on pempek industry development with data variation magnitude of $73.8 \%$. This factor classes was shown in Table 1 .

Table 1. Results of respondents data processing $(n=95)$ by using factor analysis

\begin{tabular}{llll}
\hline Factor class & Description & $\%$ variation & \% cummulative \\
\hline 1 & Organoleptic & 0.202 & 0.202 \\
2 & Product price & 0.161 & 0.363 \\
3 & Food Cleanlines and Safety & 0.155 & 0.518 \\
4 & Physical and Chemical Qualities & 0.122 & 0.640 \\
5 & Business location & 0.098 & 0.738 \\
\hline
\end{tabular}

\section{Factor 1: Organoleptic factor of pempek}

This factor determines pempek quality organoleptically and is important consideration factor for consumers in buying pempek product. The pempek's characteristics which expected by consumers are yellowish white in color, non-dominant fish taste, soft texture and rubbery, lean to strong fish taste and relatively has porous form.

Pempek's taste and rubbery are affected by formula of fish and starch used in pempek processing because starch can bind taste compounds from fish. Delicious taste on pempek is due to the availability of monosodium glutamate, 5-inosin monophospate and 5-guanosine monophospate compounds. According to Deman (1989), the existence of sulphide volatile compound, ribose sugar, glucose and glucose-6-posphate affect fish taste, whereas hidrogen sulphide, methyl marcaptan and dimethyl sulphide affect fish aroma. Pempek rubberiness is affected by amylose magnitude from starch as well as gel formation by colagen protein and sarcoplasm protein (Zayas, 1997).

Table 2. Organoleptic factors of pempek

\begin{tabular}{lll}
\hline No. & Statement & Loading \\
\hline 1 & Pempek taste affects industrial development & 0.837 \\
2 & Pempek color affects industrial development & 0.886 \\
3 & Pempek rubberiness affects industrial development & 0.844 \\
4 & Pempek aroma affects industrial development & 0.640 \\
5 & Pempek odor affects industrial development & 0.607 \\
6 & Total acceptance of pempek affects industrial development & 0.566 \\
\hline
\end{tabular}

\section{Factor 2: Price}

The offered price should be affordable by consumers and as information mean for consumers so that it can stimulatere buying. The developed strategy is moving stronghold strategy, i.e. hold out condition by expanding the marketing area or increasing the selling by decreasing cost (Supranto and Nanfan, 2007).

Table 3. Factor of product price

\begin{tabular}{lll}
\hline No. & Statement & Loading \\
\hline 1 & Price affects pempek industrial development & 0.764 \\
\hline
\end{tabular}

\section{Factor 3: Food Clean lines and Safety}

The implementation of food safety management quality (HACCP) and International Organization for Standardization (ISO) systems should be applied to all food product producers so that consumers receive their rights in term of safety and high quality products (Sutrisno et al., 2013).

HACCP is management system of preventive food safety monitoring and handling that characterized by 
scientific, rational and systematic aspects with objective to identify, to monitor and to control hazards starting from raw materials, during production/processing processes, manufacturing, handling and the use of food materials in order to guarantee that food materials are safe to be consumed (Taguchi, 2000.).

Hygiene and sanitation are indicated by 13 indicators. Indonesia should have quality improvement and establishment program for its reliable products such as pempek. Each region either at province level or district level should have similar program even with regional autonomy right that had been already put into effect. This program should be developed and improved in case of food industry through extension service certificate program by Health Department (Kadarisman. 2000).

Table 4. Factors of food clean lines and safety

\begin{tabular}{lll}
\hline No. & Statement & Loading \\
\hline 1 & Condition of processing facilities environment & 0.466 \\
2 & Environmental pest condtion & 0.246 \\
3 & General condition of processing facilities & 0.256 \\
4 & Processing room condition & 0.424 \\
5 & Facilities completeness condition & 0.443 \\
6 & Condition of processing facilities sanitation & 0.558 \\
7 & Waste handling condition & 0.638 \\
8 & Pest condition within processing room & 0.242 \\
9 & Equipments condition & 0.468 \\
10 & Employee hygiene condition & 0.675 \\
11 & Condition of packaging materials warehouse & 0.278 \\
12 & Control action & 0.347 \\
13 & Packaging and labelling condition & 0.274 \\
\hline
\end{tabular}

The implementation of GMP (sanitation and hygiene) and HACCP (Hazard Analysis and Critical Control Point) should be conducted in order to fulfill food safety requirement.

\section{Factor 4: Physical and chemical qualities}

The physical and chemical qualities have highly significant effect on pempek quality and consumers acceptance. Physical quality is represented by texture (rubberiness) and pempek's whiteness degree. The physical and chemical qualities are highly affected by formula, dough mixture, cooking condition, time and storage method. Measurement of whiteness degree is determined by color scale which is based on color sensing of human's eye that contain three receptors of red, green and blue. The color of pempek is combination between green color (-) and yellow color $(+)$ having medium color brightness (Soekarto. 1990).

Pempek having high protein content becomes a choice, but it is less profitable from commercialization point of view because the increase in protein content requires the increase of fish quantity resulting in increase of production cost. Lipid in raw materials will affect the expansion degree of pempek because it deters gelatinization process. High lipid acid content in pempek causes this product is easily oxidized and this process is accelerated by light, irradiation and heavy metals as well as free radicals which in turn produce rancidity (Agustini et al., 2008).

Table 5. Factor of physical and chemical qualities

\begin{tabular}{lll}
\hline No & Statement & Loading \\
\hline 1 & Texture affects pempek industrial development & 0.864 \\
2 & Whiteness degreeaffects pempek industrial development & 0.826 \\
3 & Proteincontent affects pempek industrial development & 0.656 \\
4 & Lipid content affects pempek industrial development & 0.532 \\
\hline
\end{tabular}

\section{Factor 5: Business Location}

The business location is significant factor that determine pempek industrial development. This location should be well prepared before implementation of production. The preparation of business location is consisted of layout, raw material location, production area and area of product yield. The business location is relatively important 
because it can produce high quality product and affects marketing.

Table 6. Business Location Factors

\begin{tabular}{lll}
\hline No & Statement & Loading \\
\hline 1 & Representative business location affects pempek industrial development and marketing & 0.928 \\
2 & Educational background and experience affect pempek industrial development & 0.532 \\
\hline
\end{tabular}

\subsection{SWOT Analysis}

SWOT analysis is systematic identification of factors and strategies which reflect both of factors and strategies based on the expected point of view of consumers. The strategies that can be selected according to SWOT analysis results were SO (strength-opportunity), WO (weakness-opportunity), ST (strength-threat) and WT (weakness-threat), respectively.

Table 7. Internal strategy off actor analysis summary (IFAS)

\begin{tabular}{|c|c|c|c|}
\hline Internal Strategy Factors & Weight & Rating & Score \\
\hline \multicolumn{4}{|l|}{ 1. Strength } \\
\hline a. High quality product with specific taste & 0.24 & 4 & 0.96 \\
\hline b. Smoothness of distribution channel & 0.21 & 4 & 0.84 \\
\hline c. Extensive market segment & 0.16 & 3 & 0.48 \\
\hline d. Appropriate and modern equipments & 0.15 & 3 & 0.45 \\
\hline e. Good public perception toward product & 0.1 & 3 & 0.30 \\
\hline f. Modern equipments & 0.04 & 3 & 0.12 \\
\hline g. Strategic business location & 0.03 & 3 & 0.09 \\
\hline h. Simple organization structure & 0.03 & 3 & 0.09 \\
\hline i. The confession existence of Palembang brand image & 0.02 & 3 & 0.06 \\
\hline j. Manpower recruitment & 0.02 & 2 & 0.04 \\
\hline Total Score & 1 & & 3.43 \\
\hline \multicolumn{4}{|l|}{ 2. Weakness: } \\
\hline a. Short shelf life of product & 0.24 & 2 & 0.48 \\
\hline b. Unavailability of informative packaging & 0.18 & 2 & 0.36 \\
\hline c. Unavailability of standard quality & 0.17 & 2 & 0.34 \\
\hline d. Relatively expensive price of pempek & 0.16 & 2 & 0.32 \\
\hline e. Limited product promotion & 0.13 & 3 & 0.39 \\
\hline f. Limited marketing network & 0.12 & 3 & 0.36 \\
\hline Total Score & 1 & & 2.25 \\
\hline
\end{tabular}

Table 8. External startegy of factor analysis summary (EFAS)

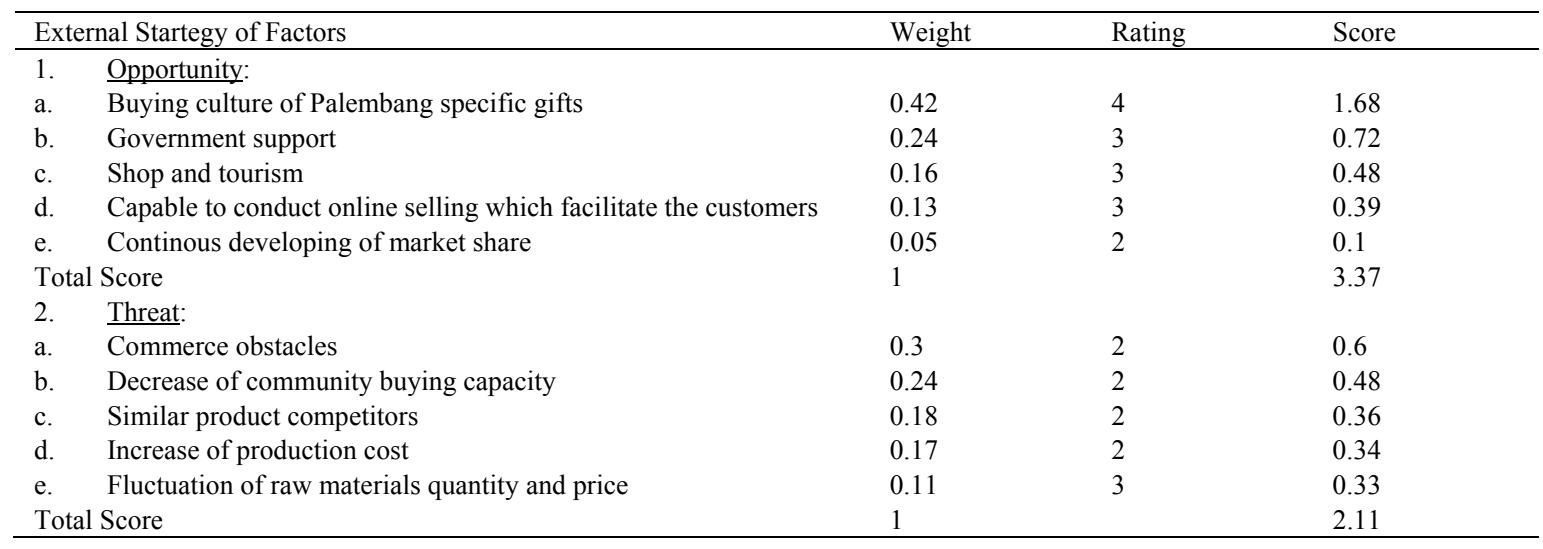


Result of strength-weakness $=3.43-2.25=1.18$

Result of opportunity-threat $=3.37-2.11=1.26$

The position is located at axis of $\mathrm{X}=1.18$ and ordinate of $\mathrm{Y}=1.26$ or it is located at first quadrant. The used and prioritized strategy was SO strategy (develop the strategy that utilize strength to make use of opportunity).

\subsection{Strategy Alternatives}

\section{S-O Strategy (strength-opportunity)}

a. Strong brand image, the company is located at strategic area and easily accessed.

b. Advertisement strategy through increasing of marketing promotion, expanding of marketing area and increasing of product varian or product diversification.

c. Clean selling area with Palembang's specifically attractiveness.

d. The existence of delivery order and drive thru which are easily utilized by consumers.

e. The increase of production capacity through time management, skil full manpower, modern machines, efficient cost, consistent quality and informative packaging.

f. Filling and expanding the prospective market shares either at national or international levels, including tourisms support.

\section{W-O Strategy (weakness-opportunity)}

a. Expanding the marketing network through collaboration with selling agents either at homeland country or foreign country, cooperation, retail shops and supermarkets as well as conducting products exhibition at homeland country or foreign country.

b. Improving the promotion strategy by utilization of low cost technology.

c. Utilization of practical and economize processing technology.

d. Increasing research and market development.

\section{S-T Strategy (Strength-Threat)}

a. Perfomance improvement of pempek processing industry by optimizing all available resources in efficient and effective manners through continous and programmed training or in-job training to employee members.

b. Increasing pempek competitiveness and quality maintenance through good monitoring in term of raw materials, processing, packaging and storage processes.

c. Increasing in homeland country consumption and global markets.

4. W- T Strategy (weakness-threat)

a. Implementing the strict quality standard through supervision effort toward producers in term of quality control.

b. Maintaining product quality and affordable price for consumers.

c. Increasing the selling promotion and advertisement of modern and hygiene pempek products with good quality by utilizing technology.

d. Socialization of quality management implementation (SNI, ISO, GMP and HACCP).

\section{Conclusion and Recommendation}

\subsection{Conclusion}

1. Factors which had significant roles in pempek industry development were organoleptic factors which consisted of taste, color, rubberiness and aroma; the afforded price for consumers, clean lines and food safety by taking into account physical quality, chemical quality, shelf life and strategic location.

2. Strategy for pempek industry development that should be done was by application of practical and economize technology, superior quality product, hygiene and safety, expanding the marketing network through collaboration with marketing agents either at homeland country or foreign country, cooperation, restaurant, retail shops and supermarkets.

3. Promotion strategy was improved through advertisement, leaflet, radio, tv, internet and publicity. 


\subsection{Recommendation}

1. Conducting the continuous innovation intern of pempek diversification as healthy and hygiene food.

2. Utilization of technological advance such as internet to increase marketing and to provide easiness for consumers.

3. The application of GMP (sanitation and hygiene) and HACCP (food safety) should be implemented in order to fulfill export quality requirement.

\section{References}

Agustini, T. W., Darmanto, Y. S., \& Putri, D. P. (2008). Evaluation on Utilization of Small Marine Fish to Produce Surimi Using Different Cryoprotective Agent to Increase the Quality of Surimi. J. Coast Develop, 11(3), 131-140.

David, F. R. (2003). Strategic Management (6th ed.). Prentice Hall International edition. New Jersey. USA.

Deman, J. M. (1989). Food Chemistry. Bandung Institute of Technology. Bandung.

Kadarisman, D. (2000). Improvement of Local Food Products in Indoensia to Fulfill International Standard. Bulletin of Technology and Food Industry. Bogor Agricultural Institute, 11(1), 70-73

Karneta, R. (2010). Economic Feasibility Analysis and Optimization of Pempek Lenjer Formulation for Industrial Scale. Journal of Human Development.Area Research and Development Council of South Sumatra Province Government, 4(3), 264-274.

Kotler, P. (1997). Marketing Management. PT Prehallindo. Jakarta.

Porter, M. E. (1998). On Competition. A Harvard Business Review Book. USA.

Rangkuti, F. (2005). SWOT Analysis: Technique for Business Case Solution. Gramedia Pustaka Utama. Jakarta.

Soekarto, S. T. (1990). Principles of Food Quality Monitoring and Standardization. Inter University Center of Food and Nutrient. Bogor Agricultural Institute. Bogor.

Steel, R. G. D., \& Torrie, J. H. (1991). Statistical Principles and Procedures. Translated by Bambang Sumantri. PT Gramedia Pustaka Utama. Jakarta.

Supranto, J., \& Nanfan, L. (2007). The Consumers Behaviour and Marketing Strategy to Win Competition. Mitra Wacana Media, Jakarta.

Sutrisno, A., Basith, A., \& Wijaya, N. H. (2013). Application Strategy Analysis of Food Safety Management System of HACCP (Hazard Analysis and Critical Control Points) in PT. Sierad Produce Tbk. Parung. Journal of Management and Organization, 4(2), 73-90.

Taguchi, G., Elsayed, E. A., \& Hsiang, T. C. (2000). Quality Engineering in Production Systems. McGraw Hill Book Co., Singapore.

\section{Copyrights}

Copyright for this article is retained by the author(s), with first publication rights granted to the journal.

This is an open-access article distributed under the terms and conditions of the Creative Commons Attribution license (http://creativecommons.org/licenses/by/4.0/). 